\title{
Isolation and identification of tumor-initiating cell properties in human gallbladder cancer cell lines using the marker cluster of differentiation 133
}

\author{
JIWEI YU, ZHAOHUI TANG, WEI GONG, MINGDI ZHANG and ZHIWEI QUAN \\ Department of General Surgery, Xinhua Hospital, Shanghai Jiao Tong University \\ School of Medicine, Shanghai 200092, P.R. China
}

Received March 27, 2016; Accepted June 29, 2017

DOI: $10.3892 / \mathrm{ol} .2017 .7159$

\begin{abstract}
The present study aimed to isolate and identify the properties of the cluster of differentiation (CD) $133^{+}$ subset in human gallbladder cancer cells. The $\mathrm{CD}_{133^{+}}$and CD133- subpopulations of the GBC-SD cell line were separated using immunomagnetic separation, and the biological features of the two subpopulations were analyzed in vitro and in vivo. In particular, the present study aimed to determine whether the two subpopulations were resistant to anti-tumor reagents and to identify the underlying molecular mechanisms involved. Following cell sorting of GBC-SD cells using immunomagnetic beads, $90.2 \pm 2 \%$ of cells were identified as $\mathrm{CD}_{133^{+}}$. Immunofluorescence confirmed that $\mathrm{CD} 133$ was expressed at higher levels in the $\mathrm{Cd} 133^{+}$group compared with the CD133- group. The proliferation of the CD133+ ${ }^{+}$group was significantly increased compared with the CD133- group in vitro and in vivo. Following treatment with fluorouracil or gemcitabine, cells in the $\mathrm{CD} 133^{+}$group exhibited a decreased sensitivity to these drugs. The number of transmembrane cells was significantly increased in the $\mathrm{CD}_{133^{+}}$group compared with the CD133 group. In addition, the expression levels of ATP binding cassette subfamily G member 2, CD44, C-X-C motif chemokine receptor 4 (CXCR4), phosphorylated-protein kinase B (Akt) and CD133 in the $\mathrm{CD}_{133^{+}}$group were significantly increased, compared with those in the CD133- group. In $\mathrm{CD}_{133^{+}} \mathrm{GBC}-\mathrm{SD}$ cells, stromal cell-derived factor $1 \alpha$ (SDF-1 $\alpha$ ) or treatment with AMD3100, an inhibitor of CXCR4, promotes or suppresses the SDF-1 $\alpha / C X C R 4$ axis, respectively, resulting in increased or decreased CD133 expression through the Akt signaling pathway. Inhibition of the Akt signaling
\end{abstract}

Correspondence to: Professor Zhiwei Quan, Department of General Surgery, Xinhua Hospital, Shanghai Jiao Tong University School of Medicine, 1665 Kongjiang Road, Shanghai 200092, P.R. China

E-mail: zhiweiquan9@126.com

Key words: gallbladder cancer, cluster of differentiation 133, tumor-initiating cell pathway resulted in decreased CD133 expression in GBC-SD cells. Immunomagnetic beads were successfully used for isolation of the $\mathrm{CD}_{133^{+}}$subset from GBC-SD cells. Furthermore, the $\mathrm{CD}_{133^{+}}$subset revealed an increased potential for tumor formation, cell proliferation, invasion and resistance to chemotherapeutic agents with expression of stem cell-associated genes. Therefore, in GBC-SD cells, the CXCR4/Akt/CD133 signaling pathways may be activated.

\section{Introduction}

Human gallbladder cancer is the most common type of malignant tumor in the biliary system worldwide (1). Since gallbladder cancer is insensitive to radiotherapy and chemotherapy and the efficiency of radical excision is between 20 and $40 \%$, and the 5-year survival rate is $5 \%$ (2). As a result, it is important to identify novel therapeutic strategies.

Tumor initiating cells (TICs) have been hypothesized to be the primary cause of tumorigenesis. This hypothesis posits that tumors exhibit a structure composed of heterogeneous subsets of cells at different stages of development, and that the initiation of a tumor is triggered by a certain subset of cells (3). As identified by Bonnet and Dick (4), TICs serve stem cell functions, and exhibit the potential for self-renewal, differentiation and tumor formation in leukemia. Previous studies have validated the TIC hypothesis in a number of types of solid tumor (5-8), and cluster of differentiation (CD)133 has been identified as a surface marker for TICs (9-11). However, it remains unknown whether $\mathrm{CD}_{133^{+}} \mathrm{TIC}$ exist in human gallbladder cancer.

Effective isolation and purification of a certain subset of tumor cells is the premise to study TICs. The approaches for isolating TICs include cell sorting by surface markers, isolation of cell colonies, isolation of side populations and screening using aldehyde dehydrogenase (12). However, identifying TICs in human gallbladder cancer remains in an exploratory stage, due to the lack of stable methods for cell sorting and the identification of biological characteristics. To perform cell sorting by surface markers, the primary approach for isolating and purifying of TICs include magnetic cell sorting (MACS) and fluorescence activated cell sorting (13). Despite progress in studying TICs in human gallbladder cancer, it remains 
unknown whether TICs exist in human gallbladder cancer, and the biological characteristics of TICs remain to be characterized $(14,15)$. In the preliminary investigations of the present study, the proportion of the $\mathrm{CD} 133^{+}$subset was determined in a number of human gallbladder cancer cell lines, and the results revealed that this cell subset was relatively increased in GBC-SD cells (14). The aim of the present study was to isolate the $\mathrm{CD}_{133^{+}}$subset from human gallbladder cancer cells using immunomagnetic separation, and identify the efficiency of cell sorting using quantitative and localization analysis. Furthermore, the present study aimed to evaluate the capabilities of the $\mathrm{CD}_{133^{+}}$subset by analyzing colony formation, tumor formation in vivo, cell proliferation, resistance to drugs, cell invasion, and the expression levels of stem cell-associated markers. The results of the present study may support the TIC hypothesis, and provide a theoretical basis for chemoresistance and tumor invasion.

The interaction between stromal cell-derived factor $1 \alpha$ (SDF-1 $\alpha$ ) and its receptor, C-X-C chemokine receptor type 4 (CXCR4), is associated with intercellular signal transduction and cell migration (16). A previous study identified that the SDF-1 $\alpha / C X C R 4$ axis served key functions in the migration, invasion and metastasis of cells in breast, prostate, lung and pancreatic cancer (17). The protein kinase B (Akt) signaling pathway primarily participates in cell growth, cell differentiation, tumor invasion and the expression of cancer-associated genes (18). Furthermore, a previous study demonstrated that the SDF-1 $\alpha / \mathrm{CXCR} 4$ axis may promote cell migration through the phosphoinositide 3-kinase (PI3K)/Akt signaling pathway (19). In addition, the present study aimed to clarify whether the SDF-1 $\alpha /$ CXCR4 and PI3K/Akt axes participated in the metastasis and invasion of human gallbladder cancer cells, and whether certain signaling pathways exist in TICs in human gallbladder cancer.

\section{Materials and methods}

Animals. A total of 155 -week old male nude mice (BCLB/c), with a body weight between 20 and $30 \mathrm{~g}$, were supplied by Shanghai Laboratory Animal Center (certificate no. 2007000544043; Shanghai, China). Mice were raised in a specific-pathogen-free feeding room at a temperature of $22-25^{\circ} \mathrm{C}, 0.03 \% \mathrm{CO}_{2}$. Mice were exposed to a 12-h light/dark cycle, and food and water was routinely provided. All experiments were performed with approval from the Animal Care and Use Committee of Xinhua Hospital, affiliated with the Medical College of Shanghai Jiao Tong University (Shanghai, China).

Cell culture and cell sorting with immunomagnetic beads. GBC-SD cells (Institute of Cell Biology, Chinese Academy of Sciences, Shanghai, China) were cultured at $37^{\circ} \mathrm{C}$ in Dulbecco's modified Eagle's medium (DMEM; Genom Biotech Pvt., Ltd., Bhandup, Mumbai) supplemented with $10 \%$ fetal bovine serum (HyClone; GE Healthcare Life Sciences, Logan, UT, USA), $100 \mathrm{U} / \mathrm{ml}$ penicillin and $100 \mathrm{U} / \mathrm{ml}$ streptomycin in an astrosphere containing $5 \% \mathrm{CO}_{2}$ and saturated humidity. Cells were passaged every 2-3 days. GBC-SD cells were selected, resuspended with $300 \mu \mathrm{l} \mathrm{PBS}$ at a density of $1 \times 10^{7}$ cells $/ \mathrm{ml}$ and sorted using MiniMACS (Miltenyi Biotec GmbH, Bergisch
Gladbach, Germany) according to the manufacturer's protocol. Following this, cells were resuspended with serum free DMEM supplemented with $20 \mathrm{ng} / \mathrm{ml}$ human epidermal growth factor (EGF) and $10 \mathrm{ng} / \mathrm{ml}$ human basic fibroblast growth factor (bFGF) (each purchased from PeproTech, Inc., Rocky Hill, NJ, USA), and divided into two groups (CD133 ${ }^{+}$and CD133 groups). Flow cytometry was used to detect the percentage of $\mathrm{CD}_{133^{+}}$cells in each group, as subsequently described.

Flow cytometry. GBC-SD cells at the logarithmic growth phase (density, $1 \times 10^{5}$ cells $/ \mathrm{ml}$ ) were used to determine the proportion of the $\mathrm{CD} 133^{+}$subset in each group using flow cytometry. GBC-SD cells were digested with $0.2 \%$ ethylene diamine tetraacetic acid-trypsin (Gibco; Thermo Fisher Scientific, Inc., Waltham, MA, USA), resuspended with $80 \mu \mathrm{l}$ PBS and adjusted to the density of $1 \times 10^{7} / \mathrm{ml}$. An aliquot of $20 \mu 1$ FcR blocking reagent (Miltenyi Biotec $\mathrm{GmbH}$ ) was added at room temperature for $1 \mathrm{~h}$. Subsequently, cells were incubated with $10 \mu \mathrm{l}$ phycoerythrin (PE-) conjugated anti-CD133 antibody (1:500 dilution; cat no. 130-080-801) or PE-conjugated immunoglobulin $\mathrm{G}$ ( $\mathrm{IgG})$ (negative control; 1:500 dilution) (both from Miltenyi Biotec $\mathrm{GmbH}$ ) at $4^{\circ} \mathrm{C}$ for $10 \mathrm{~min}$ in a dark room. Following two washes with PBS, cells were resuspended with $500 \mu \mathrm{l}$ PBS and subjected to detection by flow cytometry, as described previously (20,21), using Flowlogic (v7; Miltenyi Biotec $\mathrm{GmbH}$ ).

Immunofluorescence detection. GBC-SD cells at the logarithmic growth phase were seeded in 24-well plates at a density of $1 \times 10^{7}$ cells/well, fixed with $4 \%$ paraformaldehyde for $20 \mathrm{~min}$ at room temperature, blocked with $200 \mu \mathrm{l} 1 \%$ bovine serum albumin (Beyotime Institute of Biotechnology, Haimen, China) for $30 \mathrm{~min}$ at room temperature, and incubated with mouse anti-human CD133 monoclonal antibody (dilution, 1:11; cat no. 130-050-801; Miltenyi Biotec $\mathrm{GmbH}$ ) at $4^{\circ} \mathrm{C}$ overnight. PBS was used as a negative control. Subsequently, fluorescein isothiocyanate-labeled goat anti-mouse secondary antibody (dilution, 1:200; cat no. 115-095-003; Jackson ImmunoResearch Laboratories, Inc., West Grove, PA, USA) was added at $4^{\circ} \mathrm{C}$ for $1 \mathrm{~h}$. Cell nuclei were stained with DAPI at $4^{\circ} \mathrm{C}$ for $1 \mathrm{~h}$. Cells were subsequently observed ( 9 non-overlapping fields of view) using a Nikon ECLIPSE Ti-S fluorescence microscope (Nikon Corporation, Tokyo, Japan).

Semi-quantitative reverse transcription polymerase chain reaction $(R T-P C R)$. Total RNA was extracted from $\mathrm{CD} 133^{+}$ and CD133- GBC-SD cells using TRIzol reagent (Takara Bio, Inc., Otsu Japan), reverse transcribed into cDNA using RevertAid $^{\mathrm{TM}}$ First-Strand cDNA Synthesis kit (Sangon Biotech Co., Ltd., Shanghai China) $\left(42^{\circ} \mathrm{C}\right.$ for $30 \mathrm{~min}, 99^{\circ} \mathrm{C}$ for $5 \mathrm{~min}$ and $4^{\circ} \mathrm{C}$ for $5 \mathrm{~min}$ ), and subjected to PCR using a QuantiTect SYBR Green kit (Bimake, Houston, TX, USA) with the following reaction conditions: $94^{\circ} \mathrm{C}$ for $3 \mathrm{~min}$ followed by 35 cycles of $94^{\circ} \mathrm{C}$ for $30 \mathrm{sec}$, between 50 and $57^{\circ} \mathrm{C}$ for $30 \mathrm{sec}$, $72^{\circ} \mathrm{C}$ for $30 \mathrm{sec}$, and $4^{\circ} \mathrm{C}$ for $10 \mathrm{~min}$. The primers used were as follows: CXCR4 forward, 5'-ATCATCTTCTTAACTGGC ATTGTG-3' and reverse, 5'-GCTGTAGAGGTTGACTGT GTAG-3'; GAPDH forward, 5'-ACGGATTTGGTCGTATTG GGCG-3' and reverse, 5'-CTCCTGGAAGATGGTGATGG-3'; ABCG2 forward, 5'-GCGACCTGCCAATTTCAAAT-3' and 
reverse, 5'-AGCCAGTTGTAGGCTCATCCA-3'; CD44 forward, 5'-CAAGCAATAGGAATGATGTC-3' and reverse, 5'-GGTCACTGGGATGAAGGT-3'; EGFR forward, 5'-TAA CAAGCTCACGCAGTTGG-3' and reverse, 5'-GCCCTTCGC ACTTCTTACAC-3'; Musashi-1 forward, 5'-TAATTCCTG TCCAGCAGTCTC-3' and reverse, 5'-GAACCATCCCGT CCTGTATCAT-3'; Nanog forward, 5'-CAGCTGTGTGTA CTCAATGATAGATTT-3' and reverse, 5'-ACACCATTGCTA TTCTTCGGCCAGTTG-3'; Sox2 forward, 5'-CAAGATGGC CCAGGAGAACC-3' and reverse, 5'-GCTGCGAGTAGG ACATGCTGTA-3'; Oct-4 forward, 5'-GGCGTTCTCTTT GGAAAGGTGTTC-3' and reverse, 5'-CAAAGCTCCAGG TTCTCTTG-3'; and CD133 forward, 5'-TTACGGCACTCT TCACCT-3' and reverse, 5'-TATTCCACAAGCAGCAAA-3'.

The length of the PCR product was 228 base pairs; the annealing temperature for CXCR4 was $53^{\circ} \mathrm{C}$ and for GAPDH was $55^{\circ} \mathrm{C}$. The FusionCapt Advance FX7 (Vilber Lourmat, Marne-la-Vallée, France) was used for semi-quantitative analysis of the PCR product. PCR products were separated by electrophoresis on gels containing $2 \%$ agarose and visualized using ethidium bromide. GAPDH (Cell Signaling Technology, Inc., Danvers, MA, USA) was amplified as the control. The mRNA expression level of CXCR4 was evaluated by analyzing the ratio of gray value between CXCR4 and GAPDH, as described previously $(20,21)$.

Western blot analysis. Western blot analysis was performed as previously described $(16,17)$. GBC-SD cells $\left(1 \times 10^{5}\right)$ were digested using trypsin, treated with $100 \mu \mathrm{l}$ lysis buffer (Beyotime Institute of Biotechnology) on ice for $30 \mathrm{~min}$ and subjected to centrifugation at $4^{\circ} \mathrm{C}(11,279 \mathrm{x} \mathrm{g})$ for $5 \mathrm{~min}$. Determination of protein concentration was performed by BCA assay. Supernatant $(60 \mu \mathrm{l})$ was combined with loading buffer $(15 \mu \mathrm{l})$ and $30 \mu \mathrm{g}$ protein per lane was separated using $10 \%$ SDS-PAGE. Proteins were transferred onto a polyvinylidene fluoride (PVDF) membrane with a transfer apparatus (Bio-Rad Laboratories, Inc.). Subsequently, the PVDF membrane was blocked with 5\% non-fat milk powder diluted in TBST at room temperature for $2 \mathrm{~h}$ and incubated with the following primary monoclonal antibodies (all diluted to 1:200): Mouse anti-human CD133 (cat no. 130-105-226; Miltenyi Biotec $\mathrm{GmbH}$ ), rabbit anti-human Snail (cat no. 3879s), rabbit anti-epithelial (E-)cadherin (cat no. 3195s), mouse anti-human neural (N-)cadherin (cat no. 13116s), rabbit anti-human Akt (cat no. 4685s), rabbit anti-human phosphorylated (p-)Akt (cat no. 4060s), rabbit anti-human extracellular signal-regulated kinase (Erk; cat no. 4695s), rabbit anti-human p-Erk (cat no. 4370s) (all from Cell Signaling Technology, Inc.), or rabbit anti-human CXCR4 (cat no. ab124824; Abcam, Cambridge, MA, USA) at $4^{\circ} \mathrm{C}$ overnight. PVDF membrane was subsequently washed for $10 \mathrm{~min}$ with Tris-buffered saline (TBS) and Tween-20 (TBST) 3 times. PVDF membrane was incubated with horseradish peroxidase-labeled goat anti-rabbit or anti-mouse IgG secondary antibodies (dilution, 1:2,000; cat nos. 111-225-144 and 115-685-205, respectively; Jackson ImmunoResearch Laboratories, Inc.) at room temperature for $2 \mathrm{~h}$. Subsequently, the membranes were washed for 10 min with TBST twice and once with TBS for $10 \mathrm{~min}$, and developed using enhanced chemiluminescence (Immobilon Western Chemiluminescent HRP substrate; EMD Millipore,
Billerica, MA, USA). Films were scanned using Universal Hood II-S.N.76S/01406 (Bio-Rad Laboratories, Inc.). Semi-quantitative analysis was performed using Quantity One software (version 4.62; Bio-Rad Laboratories, Inc.). All experiments were done in triplicate. Mean values were calculated.

Comparison of proliferation ability in vitro. Target cells in the $\mathrm{CD}_{133^{+}}$or CD133 group were resuspended in DMEM containing EGF $(20 \mathrm{ng} / \mathrm{ml})$ and $\mathrm{bFGF} 10 \mathrm{ng} / \mathrm{ml})$, seeded in 96-well plates (density, $1 \times 10^{4}$ cells/well) with a final volume of $100 \mu 1$, and cultured at $37^{\circ} \mathrm{C}$ in an atmosphere containing 5\% $\mathrm{CO}_{2}$. After $24 \mathrm{~h}$, the proliferative ability of cells in each group was compared following the addition of $10 \mu \mathrm{l}$ Cell Counting Kit-8 (CCK-8) reagent (Cayman Chemical Company, Ann Arbor, MI, USA) every $24 \mathrm{~h}$ for 7 days. Cells were allocated into 1 blank control group and 6 experimental groups, for which the mean was taken. Absorbance was determined at $450 \mathrm{~nm}$ using the Model 680 (Bio-Rad Laboratories, Inc.), as previously described (21).

Drug sensitivity analysis. Target cells were resuspended in DMEM containing EGF (20 $\mathrm{ng} / \mathrm{ml})$ and bFGF (10 $\mathrm{ng} / \mathrm{ml})$, seeded in 96 -well plates (density, $1 \times 10^{4}$ cells/well) with a final volume of $100 \mu \mathrm{l}$, and cultured at $37^{\circ} \mathrm{C}$ in an atmosphere containing $5 \% \mathrm{CO}_{2}$ for $24 \mathrm{~h}$. Subsequently, $0.1 \mu \mathrm{g} / \mathrm{ml}$ fluorouracil (5-FU) or $0.1 \mu \mathrm{g} / \mathrm{ml}$ gemcitabine was added. After $72 \mathrm{~h}$, $10 \mu \mathrm{l} \mathrm{CCK}-8$ reagent was added, cells were incubated at $37^{\circ} \mathrm{C}$ for $2 \mathrm{~h}$ and absorbance at $450 \mathrm{~nm}$ was determined. The mean values were calculated to compare the proliferation rates. The blank control sample was identical but did not contain cells. Inhibition efficiency was calculated as follows: Absorbance (experimental group)/absorbance (blank group) (21).

Colony formation assay. Single cells were obtained from the $\mathrm{CD}_{133^{+}}$or $\mathrm{CD} 133^{-}$groups through limiting dilution, and cells were seeded into 96-well plates and cultured with $100 \mu \mathrm{l}$ serum-free DMEM supplemented with EGF and bFGF for $24 \mathrm{~h}$ at $37^{\circ} \mathrm{C}$. Colony formation was observed under an inverted light microscope at X10 magnification. A total of 50 wells containing a single cell were observed and colony formation efficiency was calculated as follows: Number of wells with colonies $/ 50$, as described previously (21).

Signal pathway inhibitors. Cells were incubated with SDF-1 $\alpha$ (PeproTech, Inc., Rocky Hill, NJ, USA) or an equivalent volume of vehicle at $25,50,100$ and $200 \mathrm{ng} / \mathrm{ml}$ for $2 \mathrm{~h}$ and in $37^{\circ} \mathrm{C}$ for western blotting and at $100 \mathrm{ng} / \mathrm{ml}$ for $2 \mathrm{~h}$ for all other experiments. To explore the CXCR4/Akt/CD133 signaling pathway, cells were pre-incubated with $40 \mu \mathrm{mol} / \mathrm{l}$ of the CXCR4 inhibitor AMD3100 (Sigma-Aldrich; Merck KGaA, Darmstadt, Germany) or PI3K inhibitor LY294002 (Cayman Chemical Company) which inhibit the PI3K/Akt pathway, for $30 \mathrm{~min}$ at $37^{\circ} \mathrm{C}$.

Tumor formation assay in nude mice. Unsorted cells and cells from the $\mathrm{CD}_{133^{+}}$and $\mathrm{CD} 133^{-}$subsets were seeded into the left armpit of nude mice (density, $1 \times 10^{5}$ cells $/ \mathrm{ml}$ ), and PBS was injected into the opposite side as the negative control. A total of 5 mice were used in each group. Tumor formation efficiency was calculated as the number of mice with tumor 
formation. Mice were sacrificed 4 weeks later. Tumors were selected, subjected to hematoxylin eosin staining and immunohistochemical staining for histopathological examination under light magnification at x20 magnification, as previously described $(20,21)$.

Transwell invasion assay. Matrigel (BD Biosciences, Franklin Lakes, NJ, USA) was diluted with serum free DMEM at a ratio of 1:1. The Transwell plates were from Corning Incorporated (Corning, NY, USA) and the upper chamber was coated with $50 \mu \mathrm{l}$ diluted Matrigel and incubated at $37^{\circ} \mathrm{C}$ in a cell incubator until the Matrigel solidified. $\mathrm{CD}_{133^{+}}$and $\mathrm{CD} 133^{-}$cells in the logarithmic growth phase were resuspended with serum-free DMEM medium and $100 \mu \mathrm{l}$ cells were seeded in the upper chamber (density, $1-5 \times 10^{5}$ cells/well). DMEM medium supplemented with $20 \%$ fetal bovine serum was added to the lower chamber of the Transwell insert. Following $24 \mathrm{~h}$ of culture at $37^{\circ} \mathrm{C}$, Matrigel and the cells on the upper surface of the Transwell chamber were wiped off with a cotton swab. Cells were fixed with $4 \%$ paraformaldehyde for $20 \mathrm{~min}$ and stained with crystal violet at $4^{\circ} \mathrm{C}$ for $20 \mathrm{~min}$. Subsequently, an Nikon ECLIPSE Ti-S inverted confocal microscope (Nikon Corporation) was used for observation at high magnification (x200) in 9 independent visual fields. The number of transmembrane cells was counted, and the mean value was calculated as previously described (22).

Statistical analysis. SPSS software (version 17.0; SPSS, Inc., Chicago, IL, USA) was used for statistical analysis. All data were presented as the mean \pm standard deviation. One-way analysis of variance was used for comparison between groups. $\mathrm{P}<0.05$ was considered to indicate a statistically significant difference.

\section{Results}

Purity of sorted cells. GBC-SD cells were divided into $\mathrm{CD}_{133^{+}}$or $\mathrm{CD} 133^{-}$groups using MACS with the CD133 marker. As determined using immunofluorescence, CD133, located in the surface of GBC-SD cells, was expressed at an increased level in the $\mathrm{CD}_{133^{+}}$group compared with that in the CD133- group (Fig. 1A). Flow cytometry detection indicated that the proportion of the $\mathrm{CD}_{133^{+}}$subset in the $\mathrm{CD}_{133^{+}}$group was significantly increased compared with that in the CD133 group (90.2 \pm 2 and $17.4 \pm 3 \%$, respectively; $\mathrm{P}=0.001$; Fig. 1B). Semi-quantitative RT-PCR determined that the relative gray value of CD133 mRNA in the CD133+ group was significantly increased compared with that in the $\mathrm{CD}^{-} 3^{-}$group $(0.7734 \pm 0.0217$ and $0.2146 \pm 0.0174$, respectively; $\mathrm{P}=0.001$; Fig. 1C). Data from western blot analysis indicated that the relative gray value of the CD133 protein in the $\mathrm{CD}_{133^{+}}$group was significantly increased compared with that in the CD133- group $(0.3689 \pm 0.0375$ and $0.0345 \pm 0.0040$, respectively; $\mathrm{P}=0.003$; Fig. 1D).

Colony formation and tumor formation assay. $\mathrm{CD} 133^{+}$cells were subjected to limiting dilution and seeded into 96-well plates with a single cell in each well. After 5 days of culture, between 2 and 3 cells were observed in each well. After 9 days, cell spheres were identified and, 20 days subsequently, sphere colonies with an oval or round shape were observed. Colony formation efficiency in the $\mathrm{CD}_{133^{+}}$group was significantly increased compared with that that in the CD133- group (36.25 \pm 2.99 and $4.5 \pm 1.29 \%$, respectively; $\mathrm{P}=0.006$; Fig. $2 \mathrm{~A}$ and $\mathrm{B}$ ). Cells in each group were seeded into the left armpit of nude mice at the density of $1 \times 10^{5}$ cells $/ \mathrm{ml}$. After 5 weeks, tumor formation efficiency in the $\mathrm{CD}_{133^{+}}$group and unsorted group was 100 and $60 \%$, respectively, and no tumor was observed in the CD133 group. The shape of the xenograft tumor was oval or round, and the color of the section was pale. Under a light microscope, the hematoxylin and eosin-stained section of the xenograft tumor revealed atypia and invasive growth, and cells were assembled into crypt-like structures. In addition, irregular mitosis was observed. Cells were abnormally assembled in general. As indicated by immunohistochemistry, granules representing the expression of CD133 were localized in the cell membrane and cytoplasm (Fig. 2C).

Cell proliferation and drug resistance assay. Doubling time was used to determine the in vitro proliferation ability of $\mathrm{CD}_{133^{+}}$and $\mathrm{CD} 133^{-}$cells. On day 1, the absorbance in the $\mathrm{CD}_{133^{+}}$group revealed no significant difference when compared with that in the CD133- group $(0.1070 \pm 0.0075$ and $0.1032 \pm 0.0022$, respectively; $\mathrm{P}=0.22$ ). Between days 2 and 7 , the absorbance of cells in the CD133+ group was significantly increased compared with that in the CD133 group (day 2, $0.1950 \pm 0.0214$ vs. 0.1190 $\pm 0.0109, \mathrm{P}=0.0047$; day $3,0.2607 \pm 0.0435$ vs. $01575 . \pm 0.0048, P=0.0110$; day $4,0.4122 \pm 0.0104$ vs. $0.1932 \pm 0.0169, P=0.0001$; day 5 , $0.6265 \pm 0.0546$ vs. $0.2790 \pm 0.0357, P=0.0014$; day 6 , $0.7335 \pm 0.0776$ vs. $0.3825 \pm 0.0160, P=0.0008$; day 7 , $0.7982 \pm 0.0217$ vs. $0.4320 \pm 0.0606, \mathrm{P}=0.0013$, respectively; Fig. 3A). As determined using a CCK-8 assay, following treatment with $0.1 \mu \mathrm{g} / \mathrm{ml} 5-\mathrm{FU}$, the inhibition rate of cell proliferation in the CD133- group was significantly increased compared with in the $\mathrm{CD}_{133^{+}}$group $(0.6435 \pm 0.0544$ and $0.4620 \pm 0.0404$, respectively; $\mathrm{P}=0.005)$. In addition, treatment with $1 \mu \mathrm{g} / \mathrm{ml}$ gemcitabine resulted in a significantly increased inhibition rate of cell growth in the CD133 group compared with that in the $\mathrm{CD}_{133^{+}}$group $(0.7185 \pm 0.0301$ vs. $0.3895 \pm 0.0417$, respectively; $\mathrm{P}<0.001$; Fig. $3 \mathrm{~B})$.

Cell invasion and epithelial-mesenchymal transition (EMT). As determined using the Transwell assay, the number of transmembrane cells in the $\mathrm{CD}_{133^{+}}$group was significantly increased compared with that in CD133- group (23.78 \pm 8.74 vs. $6.56 \pm 3.09$, respectively; $\mathrm{P}=0.0007$; Fig. $4 \mathrm{~A}$ and $\mathrm{B}$ ). Subsequently, the expression of EMT-associated proteins was conducted using western blot analysis. The results of the present study revealed that the expression of Snail and N-cadherin in the $\mathrm{CD}_{133}{ }^{+}$group were significantly increased, compared with those in the CD133- group $(1.4321 \pm 0.0448$ vs. $0.3489 \pm 0.0162$, $\mathrm{P}=0.006$; and $1.5061 \pm 0.1650$ vs. $0.5539 \pm 0.0279 ; \mathrm{P}=0.004$, respectively). The expression of E-cadherin in the $\mathrm{CD} 133^{+}$ group was significantly decreased compared with that in the CD133- group (0.8455 \pm 0.0453 vs. $1.7998 \pm 0.2114$, respectively; $\mathrm{P}=0.016$; Fig. 4C and D).

Expression of stem cell-associated genes. The results of the semi-quantitative RT-PCR assay indicated that the gray values 
A

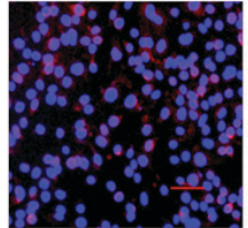

$\mathrm{CD} 133^{+}$

C

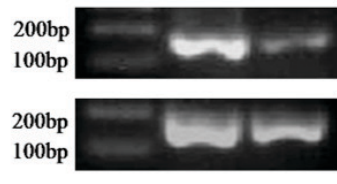

$\mathrm{CD}^{2} 33^{+} \mathrm{CD} 133$

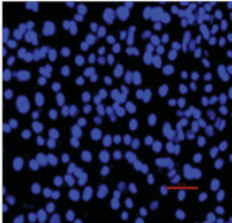

CD133-

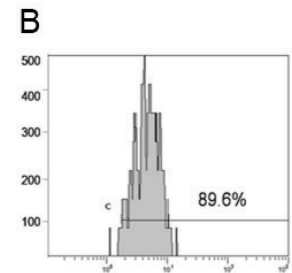

CD133+

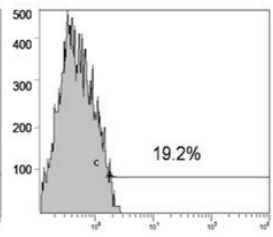

CD133-

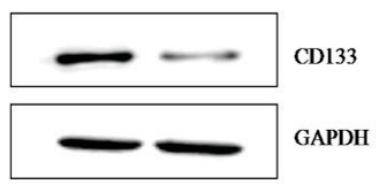

$\mathrm{CD}_{133^{+}} \mathrm{CD} 133$

Figure 1. CD133 expression in the human gallbladder cancer cell line GBC-SD following cell sorting using immunomagnetic beads. (A) Transmembrane CD133 expression in $\mathrm{CD}_{133^{+}}$and CD133- groups. CD133 was labeled with red fluorescence as indicated by arrows (magnification, $\mathrm{x} 200$ ). (B) Proportion of the $\mathrm{CD}_{133^{+}}$subset in the $\mathrm{CD}_{133^{+}}$and $\mathrm{CD} 133^{-}$groups in GBC-SD cells, determined using flow cytometry. (C) Detection of CD133 mRNA expression using polymerase chain reaction. GADPH was used as the control. (D) Detection of CD133 protein expression using western blot analysis. GADPH was used as the loading control. CD, cluster of differentiation.

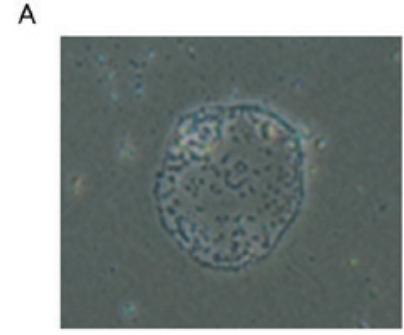

Clone formation cells

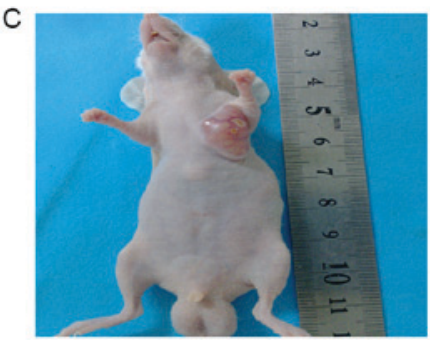

Transplanted tumor
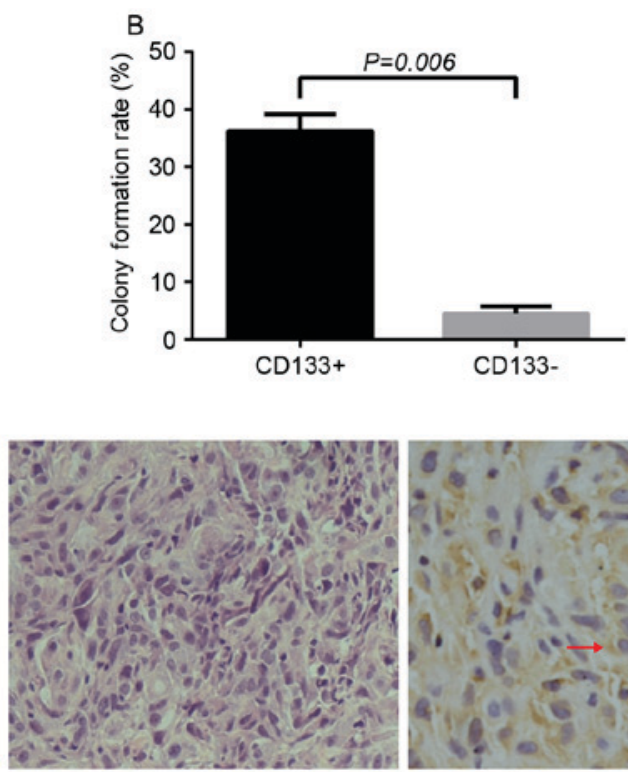

$\mathrm{H} \& E$ staining

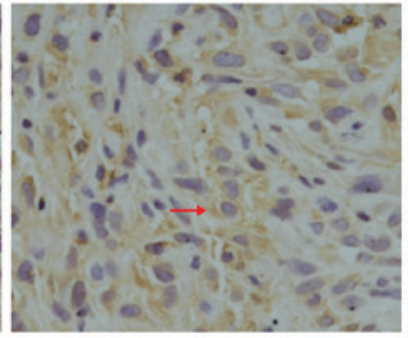

CD133 IHC staining

Figure 2. Colony formation assay and in vivo tumor formation assay. (A) Shape of the colony formed by the CD133 subset (magnification, x10). (B) Colony formation efficiency in $\mathrm{CD}_{133^{+}}$and $\mathrm{CD} 133^{-}$groups. (C) Representative images of the xenograft tumors formed by $\mathrm{CD} 133^{+}$cells, with representative $\mathrm{HE}$ staining and CD133 IHC staining, as observed under an inverted microscope (magnification, x200). The arrow indicates CD133 ${ }^{+}$cells. CD, cluster of differentiation; H\&E, hematoxylin and eosin; IHC, immunohistochemistry.

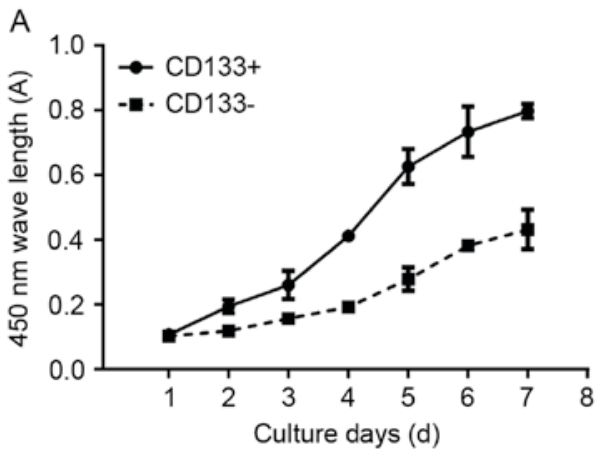

B

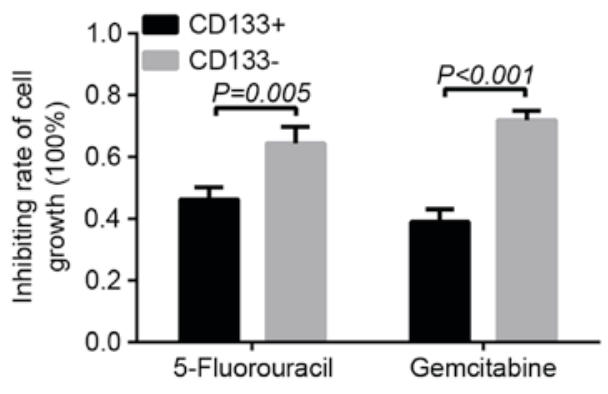

Figure 3. Cell biology characteristics of cells in the $\mathrm{CD}_{133^{+}}$and CD133 groups. (A) Comparison of the proliferative ability between the CD133 ${ }^{+}$and $\mathrm{CD} 133$ groups. (B) Inhibiting rate of cell growth in the $\mathrm{CD} 133^{+}$and $\mathrm{CD} 133^{-}$groups $72 \mathrm{~h}$ after treatment with 5-fluorouracil or gemcitabine. $\mathrm{CD}$, cluster of differentiation. 


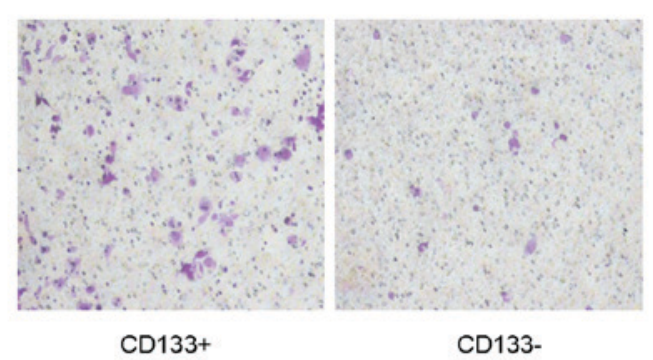

C

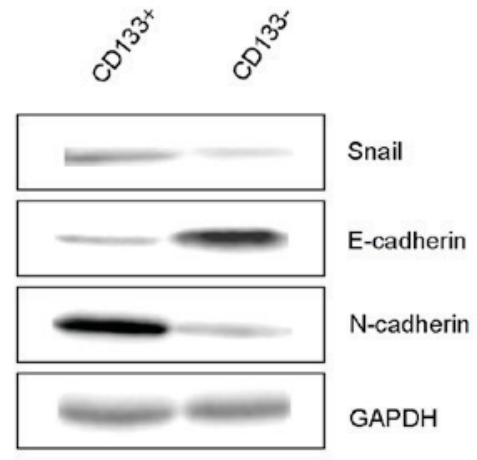

B 50
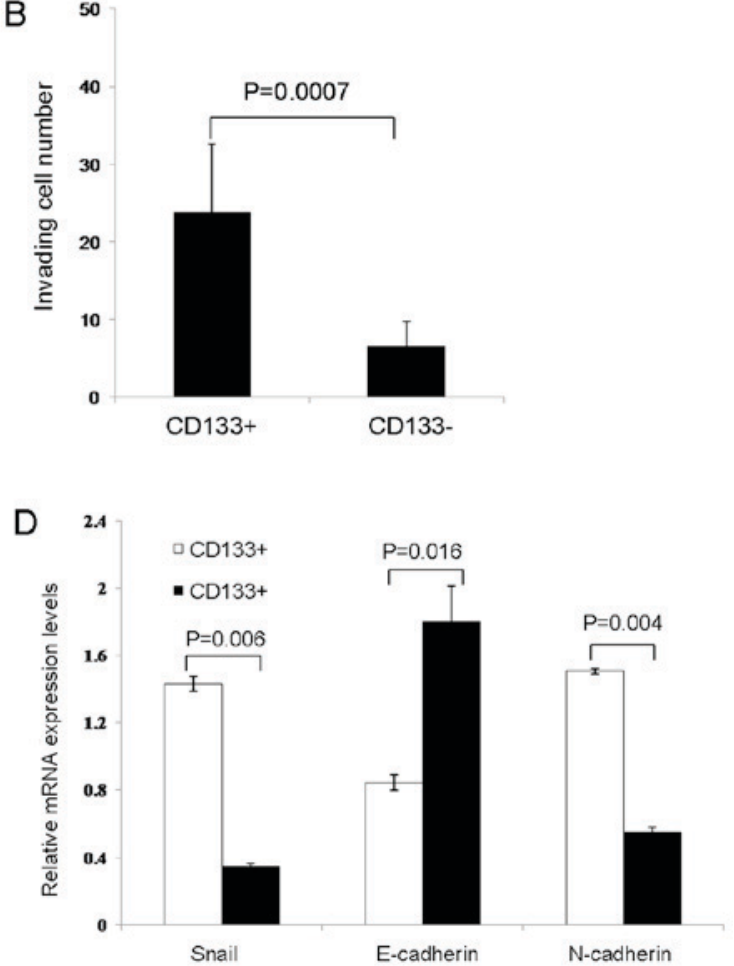

Figure 4. Cell invasion and EMT. (A) Number of transmembrane cells in the CD133+ and CD133- groups, observed under an inverted microscope (magnification, x200). (B) Quantitative analysis of the number of invasive cells. (C) Expression of EMT-associated proteins in the CD133 ${ }^{+}$and CD133- groups. (D) Quantitative analysis of mRNA expression of EMT-associated genes in the CD133+ and CD133- groups. EMT, epithelial-mesenchymal transition; CD, cluster of differentiation.

of ATP-binding cassette sub-family G member 2 (ABCG2) and CD44 mRNA in the $\mathrm{CD}_{133^{+}}$group were significantly increased compared with those in the CD133' group $(0.8774 \pm 0.0191$ vs. $0.3276 \pm 0.0272, \mathrm{P}=0.001$; and $1.3681 \pm 0.0879$ vs $0.7891 \pm 0.0385, \mathrm{P}=0.005$, respectively). The expression of EGF-receptor, Musashi-1, Nanog, sex determining region Y-box 2, and octamer-binding transcription factor-4 mRNA did not significantly differ between the two groups (CD133 ${ }^{+}$ group, $0.1541 \pm 0.0221,0.1057 \pm 0.0122,0.1088 \pm 0.0562$, $0.1266 \pm 0.0207$ and $0.1424 \pm 0.0168$, respectively; CD133 group, $0.1252 \pm 0.0384,0.1334 \pm 0.0194,0.1175 \pm 0.0188,0.1275 \pm 0.0159$, and $0.1411 \pm 0.0289$, respectively; $\mathrm{P}=0.241, \mathrm{P}=0.070, \mathrm{P}=0.364$, $\mathrm{P}=0.462$, and $\mathrm{P}=0.472$, respectively; Fig. $5 \mathrm{~A}$ and $\mathrm{B}$ ).

Regulation of the CXCR4/Akt/CD133 signaling pathway. As determined using western blot analysis, the relative gray value referring to the expression level of proteins CXCR4, p-AKT and CD133 were significantly increased in the $\mathrm{CD}_{133^{+}}$group compared with those in the CD133- group $(0.5427 \pm 0.0135$ vs. $0.2770 \pm 0.0378, \mathrm{P}=0.001 ; 0.4207 \pm 0.0291$ vs. $0.2187 \pm 0.0035$, $\mathrm{P}=0.005$; and $0.5349 \pm 0.069$ vs. $0.2906 \pm 0.0259, \mathrm{P}=0.003$, respectively, Fig. 6A). The expression levels of Akt, p-Erk and Erk revealed no statistically significant differences between the two groups $\left(\mathrm{CD} 133^{+}\right.$group, $0.4098 \pm 0.0105,0.6614 \pm 0.0320$ and $0.6914 \pm 0.040$, respectively; CD133 group, $0.3759 \pm 0.0323$, $0.6608 \pm 0.0623$ and $0.6627 \pm 0.0237$, respectively; $\mathrm{P}=0.104$, $\mathrm{P}=0.493$, and $\mathrm{P}=0.084$, respectively; Fig. $6 \mathrm{~A}$ ).

SDF-1 $\alpha$, an activator of CXCR4, was then introduced into the study. Treatment with SDF- $1 \alpha$ for $2 \mathrm{~h}$ at different concentrations $(25,50,100$ and $200 \mathrm{ng} / \mathrm{ml})$ resulted in increased protein expression levels of CD133, CXCR4 and p-Akt in GBC-SD cells compared with those in the untreated group (Fig. 6B). When SDF-1 $\alpha$ was used at a concentration of $100 \mathrm{ng} / \mathrm{ml}$, protein expression reached the peak value and the level of expression decreased following treatment with $200 \mathrm{ng} / \mathrm{ml}$ SDF-1 $\alpha$. Following treatment with SDF-1 $\alpha$ (100 ng/ml), the expression of CD133, CXCR4 and p-Akt in GBC-SD cells was determined at different time points (15, $30 \mathrm{~min}, 1,2$ and 24 h). Compared with those in the untreated group, the expression level of these proteins increased $30 \mathrm{~min}$ following treatment, reached the peak value $2 \mathrm{~h}$ following treatment, and began to decrease at $24 \mathrm{~h}$ following treatment (Fig. 6B).

In order to identify the associations between CD133 and CXCR4, the activator and inhibitor of CXCR4 (SDF-1 $\alpha$ and AMD3100, respectively) and the inhibitors of PI3K/Akt and mitogen-activated protein kinase/ERK signaling pathways were used to treat the $\mathrm{CD}_{133^{+}}$and $\mathrm{CD} 133^{-}$groups. In the $\mathrm{CD} 133^{+}$group, SDF-1 $\alpha$ treatment induced significantly increased expression of CD133 and CXCR4 mRNA expression. Following treatment, with AMD3100, LY294002, or combined treatment with AMD3100 and SDF-1 $\alpha$, LY294002 and SDF-1 $\alpha$, the expression of CD133 and CXCR4 mRNAs significantly decreased in the $\mathrm{CD}_{133^{+}}$group. Additionally, in the $\mathrm{CD}_{133^{+}}$group, following treatment with PD98059 or combined treatment with PD98059 and SDF-1 $\alpha$, the expression of CD133 and CXCR4 mRNA revealed no significant difference. However, in the CD133-group, following treatment with 
A

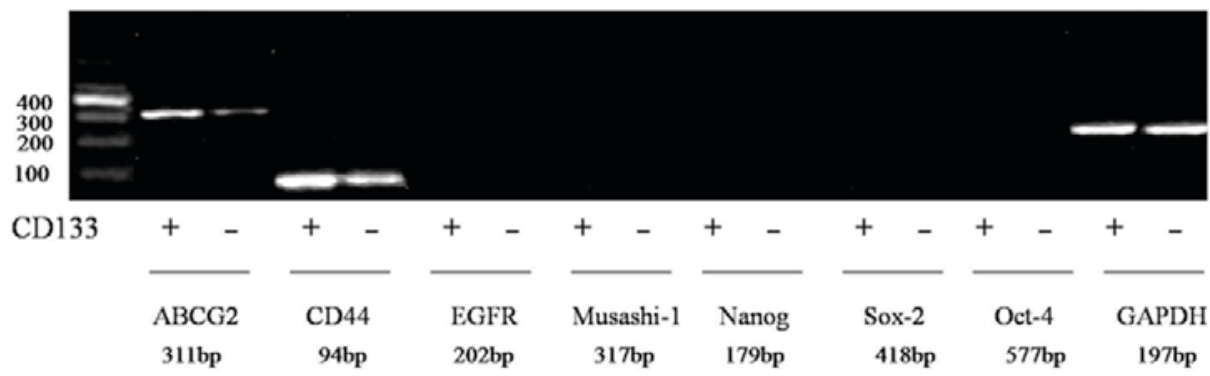

B

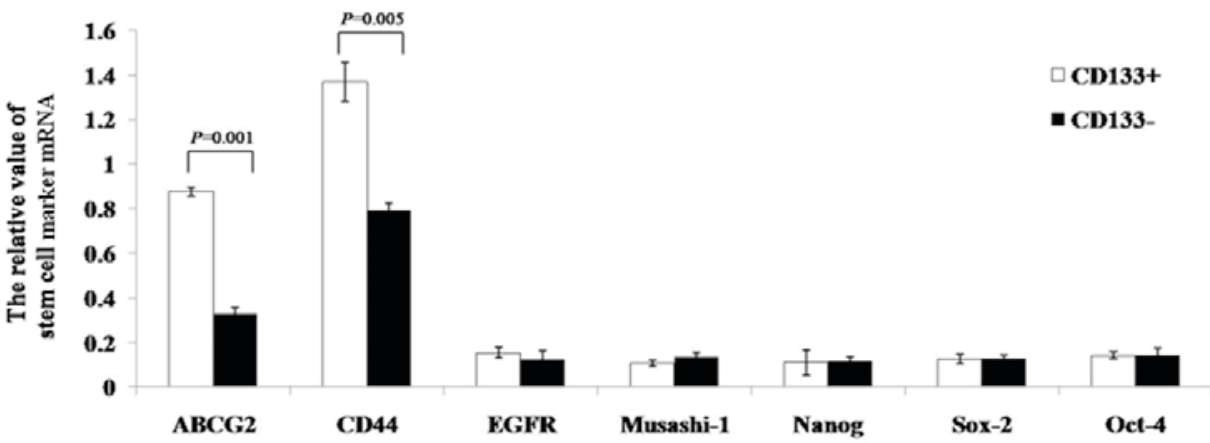

Figure 5. Expression of stem cell-associated genes. (A) DNA electrophoresis of stem cell-associated genes in the CD133+ and CD133 groups, determined using polymerase chain reaction. (B) Quantitative analysis of mRNA expression level of stem cell-associated genes. GADPH was used as the loading control. CD, cluster of differentiation; CXCR4, C-X-C motif chemokine receptor 4; p-, phosphorylated; Akt, protein kinase B; Erk, extracellular signal-regulated kinase; SDF-1 $\alpha$, stromal cell-derived factor $1 \alpha$.

A

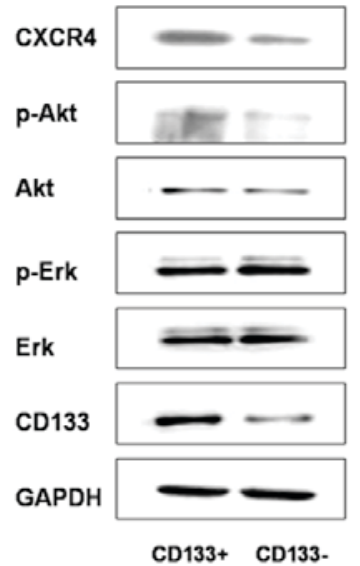

B

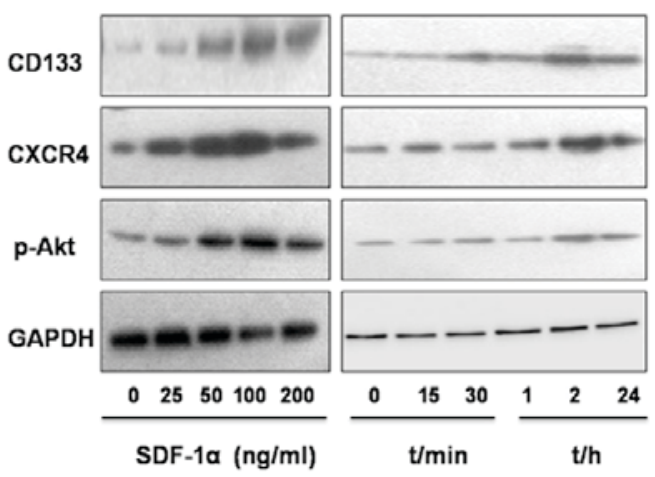

Figure 6. Regulation of the CXCR4/Akt/CD133 signaling pathway. (A) Differences in CXCR4/Akt/CD133 protein expression between the CD133+ and CD133 group. (B) Protein expression of CXCR4/Akt/CD133 as induced by treatment with SDF-1 $\alpha$ at different concentrations $(25,50,100$, and 200 ng/ml) and for different durations $(15,30 \mathrm{~min}, 1,2$, and $24 \mathrm{~h})$.

SDF-1 $\alpha$, AMD3100, LY294002, PD98059, or combined treatment with AMD3100 and SDF-1 $\alpha$, LY294002 and SDF-1 $\alpha$, PD98059 and SDF-1 $\alpha$, no significant difference was observed in the mRNA expression of CD133 and CXCR4 (Fig. 7A).

The signaling pathway alterations in different groups were determined. In the $\mathrm{CD} 133^{+}$group, SDF- $1 \alpha$ treatment induced significantly increased protein expression of CXCR4, p-Ak and CD133; however, there was no significant difference determined in the expression of Akt, Erk and p-Erk. AMD3100 treatment or combined treatment with AMD3100 and SDF- $1 \alpha$ induced significantly decreased expression of p-Akt and CD133, whereas the expression of Akt, Erk, and p-Erk revealed no significant differences. LY294002 treatment or combined treatment with LY294002 and SDF-1 $\alpha$ induced significantly decreased expression of p-Akt and CD133, whereas the expression of CXCR4, Akt, Erk and p-Erk revealed no significant differences. PD98059 treatment or combined treatment with PD98059 and SDF-1 $\alpha$ induced significantly decreased expression of p-Akt; however, the expression of CXCR4, Akt, p-Akt, Erk and CD133 revealed no significant differences (Fig. 7B). In the CD133 group, following treatment with SDF-1 $\alpha$, AMD3100, LY294002, PD98059, or combined treatment with AMD3100 and SDF-1 $\alpha$, LY294002 and SDF-1 $\alpha$, PD98059 and SDF-1 $\alpha$, no significant differences were observed in CXCR4, p-Akt, Akt, Erk, p-Erk and CD133 protein expression (Fig. 7B). The CXCR4/Akt/CD133 axis 


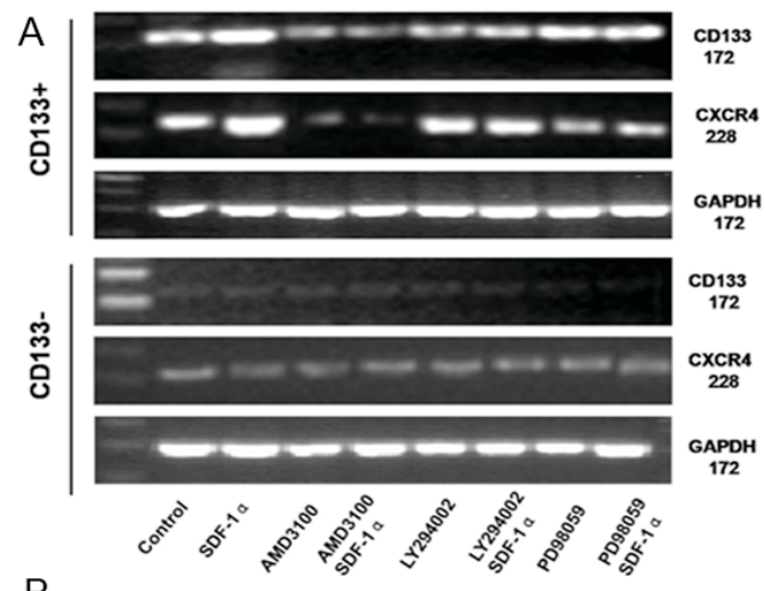

B
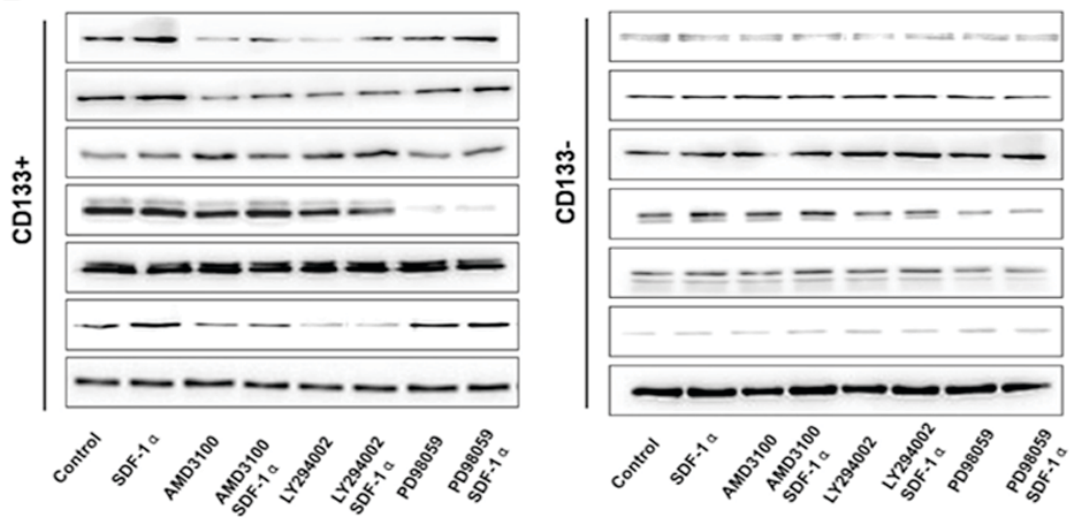

CXCR4

p-Akt

Akt

p-Erk

Erk

CD133

GAPDH

Figure 7.(A)CD133 and CXCR4 mRNA expression profiles in the CD133+ and CD133 groups following treatment with SDF-1 $2 /$ AMD3100/LY294002.(B) CXCR4, p-Akt, Akt, p-Erk, Erk, and CD133 protein expression profiles in the CD133 ${ }^{+}$and CD133- groups following treatment with SDF-1 $\alpha /$ AMD3100/LY294002. The CXCR4/Akt/CD133 axis and its potential function. CXCR4, C-X-C motif chemokine receptor 4; Akt, protein kinase B; CD, cluster of differentiation; SDF-1 $\alpha$, stromal cell-derived factor $1 \alpha$; p-, phosphorylated; Erk, extracellular signal-regulated kinase.

may serve an important function in the regulation of colony and tumor formation, cell proliferation and chemoresistance, cell invasion and stemness in human gallbladder cancer.

\section{Discussion}

TICs make up a small number of cells that remain in the initiation stage of differentiation (23). TICs have the ability of self-renewal, limitless proliferation and multi-directional differentiation; therefore, TICs are a key factor for the initiation of malignant proliferation, invasion, and metastasis of tumor cells. Tumor cells in the stage of terminal differentiation lose the capability of differentiation and tumorigenesis $(13,3)$.

Targeting certain cell surface markers may be a useful approach for screening for TICs. Human CD133 antigen is a 5-transmembrane glycoprotein participating in the formation of the topological structure of the cell membrane. The expression of CD133 is downregulated as cell differentiation progresses; therefore, $\mathrm{CD} 133$ has become one of the markers for the isolation and identification of tumor stem cells and/or progenitor cells (24). Studies on brain, pancreatic, colon and prostate cancer have validated CD133 as an important marker for TICs $(10-13,25)$. Previous studies have attempted to isolate TICs from gallbladder cancer, but the biological characteristics of isolated TICs remain unknown $(14,15)$. In preliminary investigations of the present study, CD133 expression in the human gallbladder cancer cell line GBC-SD was significantly increased compared with that in the human gallbladder cancer cell line SGC996. CD133 expression was located in the cell membrane at an increased level of expression. Therefore, using the human gallbladder cancer cell line GBC-SD, it may be possible to obtain abundant $\mathrm{CD} 133^{+}$-subset cells for further research into their biological characteristics.

The present study is among the first to sort $\mathrm{CD} 133^{+}$human gallbladder cancer cells using MACS. Immunofluorescence and flow cytometry analysis indicated that the purity of $\mathrm{CD}_{133^{+}}$cells in $\mathrm{CD} 133^{+}$group was significantly increased compared with that of the CD133- group, and CD133 was primarily located in the cell membrane. In addition, the mRNA and protein expression of CD133 in the $\mathrm{CD}_{133^{+}}$group was significantly increased compared with that in the CD133 group.

Tumor formation and colony formation assays are key methods of analyzing tumorigenesis capability (26). In the present study, tumor formation efficiency in the $\mathrm{CD} 133^{+}$group was $100 \%$, whereas no tumors were observed in the CD133 group. Colony formation in the $\mathrm{CD} 133^{+}$group was significantly increased compared with that of the CD133 group. The results of the present study indicated that $\mathrm{CD} 133^{+}$cells have tumorigenesis capabilities, and may contain an increased number of TICs than CD133 cells. Furthermore, following treatment with EGF and bFGF for 3 weeks, a single $\mathrm{CD} 133^{+}$cell was able to proliferate, forming dozens of cells which made up a cell sphere. Thus, a single $\mathrm{CD} 133^{+}$cell, isolated using cell sorting, 
exhibited self-renewal and colony formation abilities, as do stem cells originated from the same clone.

Limitless proliferation and resistance to drugs are the fundamental characteristics which distinguish TICs from other tumor cells $(26,27)$. The results of the present study indicated that, when cultured with serum free medium supplemented with EGF and bFGF, cells in the CD133+ group revealed significantly increased in vitro proliferative abilities compared with those in the CD133- group. Gemcitabine and 5-FU are routine chemotherapeutics in clinical use. Sorted cells in the $\mathrm{CD}_{133^{+}}$and $\mathrm{CD} 133$ groups were treated with 5-FU and gemcitabine, and drug susceptibility of the cells in the two groups was observed. The inhibiting rate of cell growth in the CD133- group was significantly increased compared with that in the $\mathrm{CD}_{133^{+}}$group, indicating that $\mathrm{CD} 133^{+}$cells exhibited decreased sensitivity to anti-tumor drugs.

EMT is a process where epithelial cells lose polarity and transform into mesenchymal cells, followed by subsequent cell migration. EMT is an important characteristic in embryonic development (28). A previous study identified that the initiation of EMT served a key function in triggering invasion and metastasis of tumor cells (29). In the present study, using an Transwell assay, cells in the CD133 ${ }^{+}$ group demonstrated significantly increased invasive abilities compared with those in the CD133- group. Furthermore, protein expression of E-cadherin, a biomarker for epithelial cells, was decreased in the $\mathrm{CD}_{133^{+}}$subset, whereas the protein expression of $\mathrm{N}$-cadherin and Snail, biomarkers for mesenchymal cells, was increased. Therefore, it may be inferred that the increased invasive ability of the CD133+ subset was obtained through the initiation of EMT.

A previous study on embryonic stem cells (ESCs) demonstrated that the transcription factors Sox-2, Oct-4 and Nanog form a key regulatory loop that controls the transcription of various mRNAs, and induces the reverse transformation of adult cells into ESCs (30). Adenosine triphosphate-binding cassette transporters (ABCs) are transmembrane pumps which transport endogenous lipids, peptides, nucleotides and mycins. The DNA dye Hoechst 33342 may be pumped out of cells by ABCG2, which is used to isolate side population cells exhibiting the characteristics similar to TICs (31). As reported by Yin et al (14), the human gallbladder cancer cell line GBC-SD formed spherical colonies under serum-free culture conditions and the stem cell markers Nanog, Oct-4, Sox-2 and ABCG2 were expressed at an increased level in spherical colonies. The Musashi family is an evolutionarily conserved RNA binding protein in neural cells which is selectively expressed in neural stem/progenitor cells (14). A previous study demonstrated that Musashi-1 is associated with the degree of malignancy, clinical pathology and prognosis in colorectal cancer (32). The EGF receptor (EGFR) is a receptor that serves important functions in cell proliferation and signal transduction, and is abnormally expressed in a number of types of solid tumor (33). In human gallbladder cancer cells, increased expression of EGFR may accelerate the process of malignant tumors through transactivation of inducible nitric oxide synthase (34). CD44 has been identified as an important marker for TICs (35). In the present study, the expression of stem cell markers in $\mathrm{CD}_{133^{+}}$cells were determined using semi-quantitative PCR, which revealed that ABCG2 and CD44 were highly expressed in $\mathrm{CD}_{133}{ }^{+}$cells and indicated that $\mathrm{CD} 44^{+}$or $\mathrm{CD} 44^{+} \mathrm{ABCG}^{+}$cells may exist in the $\mathrm{CD}_{133^{+}}$group. The expression of Nanog, Oct-4, Sox2, Musashi-1 and EGFR revealed no significant differences, and the underlying molecular mechanism of this requires additional study.

Ping et al (36) demonstrated that the SDF-1/CXCR4 axis may upregulate the expression of CD133 in glioma stem cells through the PI3K/Akt signaling pathway, and promote the formation of blood vessels. The results of the present study identified that the expression of CXCR4/Akt/CD133 signaling pathway proteins in the $\mathrm{CD} 133^{+}$group was significantly increased, compared with that in the CD133- group; therefore, it is possible to infer from these data that proteins in the CXCR4/Akt/CD133 signaling pathway were activated in human gallbladder cancer cell line GBC-SD. Furthermore, GBC-SD cells were treated with SDF-1 $\alpha$, and the intracellular expression of CXCR4, p-Akt and CD133 proteins was determined. The protein expression levels of CXCR4, p-Akt and CD133 were identified to be increased in a time-dependent manner. The present study identified that the optimal concentration of SDF-1 $\alpha$ was $100 \mathrm{ng} / \mathrm{ml}$, and the optimal duration for SDF- $1 \alpha$ treatment was $2 \mathrm{~h}$.

To determine whether the CXCR4/Akt/CD133 signaling pathway was activated, CD133 ${ }^{+}$GBC-SD cells were treated with SDF-1 $\alpha$ and AMD3100 (a specific blocker for CXCR4), and the expression of proteins in CXCR4/Akt/CD133 signaling pathway was observed. The results of the present study identified that SDF-1 $\alpha$ significantly promoted the expression of CD133 at the mRNA and protein level in CD133+ GBC-SD cells, whereas AMD3100 downregulated the expression of CD133 mRNA and protein. However, in CD133- GBC-SD cells, neither SDF-1 $\alpha$ nor AMD3100 treatment resulted in a regulatory effect on CD133 expression. Therefore, in $\mathrm{CD} 133^{+}$ GBC-SD cells, the SDF-1 $\alpha /$ CXCR4 axis participated in the regulation of CD133 expression. The underlying molecular mechanism remains unknown.

Following treatment of CD133 ${ }^{+}$GBC-SD cells with SDF- $1 \alpha$ or AMD3100, the protein expression level of p-Akt increased or decreased, whereas the expression of total Akt, p-Erk and total Erk did not change, suggesting that the SDF-1 $\alpha / \mathrm{CXCR} 4$ axis participated in the regulation of the PI3K/Akt signaling pathway. To identify the underlying molecular mechanisms associating the SDF-1 $\alpha / \mathrm{CXCR} 4$ axis with the regulation of CD133 expression, CD133 ${ }^{+}$GBC-SD cells were treated with LY294002, a specific inhibitor of the Akt signaling pathway, or PD98059, a specific inhibitor of the Erk signaling pathway, and the expression levels of proteins associated with the CXCR4/Akt/CD133 signaling pathway were determined. In $\mathrm{CD}_{133}{ }^{+}$GBC-SD cells treated with LY294002, the expression of Akt protein did not change and the expression level of p-Akt was downregulated, which resulted in downregulated expression of CD133 at the mRNA and protein level. However, PD98059 treatment did not result in altered in CD133 expression. The results from the present study suggested that the SDF-1 $\alpha /$ CXCR4 axis may participate in the regulation of CD133 expression in CD133+ GBC-SD cells through the Akt signaling pathway, but not the Erk signaling pathway. In CD133- GBC-SD cells, SDF-1 $\alpha$, AMD3100, LY294002 or PD98059 treatment did not result in significant changes to CD133 expression, indicating that the CXCR4/Akt/CD133 
signaling pathway may be specifically activated in $\mathrm{CD} 133^{+}$ GBC-SD cells.

The results of the present study revealed that, in CD133+ GBC-SD cells, SDF-1 $\alpha$ or AMD3100 may promote or suppress the SDF-1 $\alpha / \mathrm{CXCR} 4$ axis, resulting in increased or decreased expression of CD133 in GBC-SD cells through the Akt signaling pathway. Inhibition of the Akt signaling pathway may downregulate CD133 expression in human gallbladder cancer cells.

There are a limited number of previous studies isolating $\mathrm{CD}_{133^{+}}$human gallbladder cancer cells using MACS. The present study demonstrated that the $\mathrm{CD} 133^{+}$subset in human gallbladder cancer cell line GBC-SD exhibited TIC characteristics, including increased proliferative and invasive abilities, in vivo tumor formation and in vitro colony formation, and was resistant to anti-tumor drugs. Furthermore, the CXCR4/Akt/CD133 signaling pathway may be activated in $\mathrm{CD}_{133}{ }^{+}$cells from the human gallbladder cancer cell line GBC-SD.

\section{Acknowledgements}

The authors would like to thank the National Natural Science Foundation of China (grant no. 81101850) and the Department of General Surgery, Xinhua Hospital, Shanghai Jiao Tong University School of Medicine.

\section{References}

1. Park HS, Lim JY, Yoon DS, Park JS, Lee DK, Lee SJ, Choi HJ, Song SY, Lee WJ and Cho JY: Outcome of adjuvant therapy for gallbladder cancer. Oncology 79: 168-173, 2010.

2. Misra S, Chaturvedi A, Misra NC and Sharma ID: Carcinoma of the gallbladder. Lancet Oncol 4: 167-176, 2003.

3. Meacham CE and Morrison SJ: Tumour heterogeneity and cancer cell plasticity. Nature 501: 328-337, 2013.

4. Bonnet D and Dick JE: Human acute myeloid leukemia is organized as a hierarchy that originates from a primitive hematopoietic cell. Nat Med 3: 730-737, 1997.

5. Dalerba P, Dylla SJ, Park IK, Liu R, Wang X, Cho RW, Hoey T, Gurney A, Huang EH, Simeone DM, et al: Phenotypic characterization of human colorectal cancer stem cells. Proc Natl Acad Sci USA 104: 10158-10163, 2007.

6. Li C, Heidt DG, Dalerba P, Burant CF, Zhang L, Adsay V, Wicha M, Clarke MF and Simeone DM: Identification of pancreatic cancer stem cells. Cancer Res 67: 1030-1037, 2007.

7. Bao S, Wu Q, McLendon RE, Hao Y, Shi Q, Hjelmeland AB, Dewhirst MW, Bigner DD and Rich JN: Glioma stem cells promote radioresistance by preferential activation of the DNA damage response. Nature 444: 756-760, 2006.

8. Alvero AB, Chen R, Fu HH, Montagna M, Schwartz PE, Rutherford T, Silasi DA, Steffensen KD, Waldstrom M, Visintin I and Mor G: Molecular phenotyping of human ovarian cancer stem cells unravels the mechanisms for repair and chemoresistance. Cell Cycle 8: 158-166, 2009.

9. Choy W, Nagasawa DT, Trang A, Thill K, Spasic M and Yang I: CD133 as a marker for regulation and potential for targeted therapies in glioblastoma multiforme. Neurosurg Clin N Am 23 391-405, 2012.

10. Lee HJ, You DD, Choi DW, Choi YS, Kim SJ, Won YS and Moon HJ: Significance of CD133 as a cancer stem cell markers focusing on the tumorigenicity of pancreatic cancer cell lines. J Korean Surg Soc 81: 263-270, 2011.

11. Wang C, Xie J, Guo J, Manning HC, Gore JC and Guo N: Evaluation of CD44 and CD133 as cancer stem cell markers for colorectal cancer. Oncol Rep 28: 1301-1308, 2012.

12. Sugihara E and Saya H: Complexity of cancer stem cells. Int J Cancer 132: 1249-1259, 2013.

13. Kreso A and Dick JE: Evolution of the cancer stem cell model. Cell Stem Cell 14: 275-291, 2014.

14. Yin BB, Wu SJ, Zong HJ, Ma BJ and Cai D: Preliminary screening and identification of stem cell-like sphere clones in a gallbladder cancer cell line GBC-SD. J Zhejiang Univ Sci B 12: 256-263, 2011.
15. Shi CJ, Gao J, Wang M, Wang X, Tian R, Zhu F, Shen M and Qin RY: CD133(+) gallbladder carcinoma cells exhibit self-renewal ability and tumorigenicity. World J Gastroenterol 17: 2965-2971, 2011.

16. Chatterjee S, Behnam Azad B and Nimmagadda S: The intricate role of CXCR4 in cancer. Adv Cancer Res 124: 31-82, 2014.

17. Sun X, Cheng G, Hao M, Zheng J, Zhou X, Zhang J, Taichman RS, Pienta KJ and Wang J: CXCL12/CXCR4/CXCR7 chemokine axis and cancer progression. Cancer Metastasis Rev 29: 709-722, 2010.

18. Vasko V, Saji M, Hardy E, Kruhlak M, Larin A, Savchenko V, Miyakawa M, Isozaki O, Murakami H, Tsushima T, et al: Akt activation and localization correlate with tumour invasion and oncogene expression in thyroid cancer. J Med Genet 41: 161-170, 2004.

19. Friedl P and Alexander S: Cancer invasion and the microenvironment: Plasticity and reciprocity. Cell 147: 992-1009, 2011.

20. Yu JW, Zhang P, Wu JG, Wu SH, Li XQ, Wang ST, Lu RQ, Ni XC and Jiang BJ: Expressions and clinical significances of CD133 protein and CD133 mRNA in primary lesion of gastric adenocacinoma. J Exp Clin Cancer Res 29: 141, 2010.

21. Lu RQ, Wu JG, Zhou GC, Jiang HG, Yu JW and Jiang BJ: Sorting of CD133(+) subset cells in human gastric cancer and the identification of their tumor initiating cell-like properties. Zhonghua Wei Chang Wai Ke Za Zhi 15: 174-179, 2012.

22. Zhang SS, Han ZP, Jing YY, Tao SF, Li TJ, Wang H, Wang Y, Li R, Yang Y, Zhao X, et al: CD133(+)CXCR4(+) colon cancer cells exhibitmetastatic potential and predict poor prognosis of patients. BMC Med 10: 85, 2012.

23. Magee JA, Piskounova E and Morrison SJ: Cancer stem cells: Impact, heterogeneity, and uncertainty. Cancer Cell 21: 283-296, 2012.

24. O'Brien CA, Pollett A, Gallinger S and Dick JE: A human colon cancer cell capable of initiating tumour growth in immunodeficient mice. Nature 445: 106-110, 2007.

25. Vander Griend DJ, Karthaus WL, Dalrymple S, Meeker A, DeMarzo AM and Isaacs JT: The role of CD133 in normal human prostate stem cells and malignant cancer-initiating cells. Cancer Res 68: 9703-9711, 2008.

26. Reya T, Morrison SJ, Clarke MF and Weissman IL: Stem cells, cancer, and cancer stem cells. Nature 414: 105-111, 2001.

27. Singh S, Chitkara D, Mehrazin R, Behrman SW, Wake RW and Mahato RI: Chemoresistance in prostate cancer cells is regulated by miRNAs and Hedgehog pathway. PLoS One 7: e40021, 2012.

28. Thiery JP: Epithelial-mesenchymal transitions in tumour progression. Nat Rev Cancer 2: 442-454, 2002.

29. Singh A and Settleman J: EMT, cancer stem cells and drug resistance: An emerging axis of evil in the war on cancer. Oncogene 29: 4741-4751, 2010.

30. Yu J, Vodyanik MA, Smuga-Otto K, Antosiewicz-Bourget J, Frane JL, Tian S, Nie J, Jonsdottir GA, Ruotti V, Stewart R, et al: Induced pluripotent stem cell lines derived from human somatic cells. Science 318: 1917-1920, 2007.

31. Liu DC, Yang ZL and Jiang S: Identification of musashi-1 and ALDH1 as carcinogenesis, progression, and poor-prognosis related biomarkers for gallbladder adenocarcinoma. Cancer Biomark 8: 113-121, 2010-2011.

32. Lichtenberger BM, Tan PK, Niederleithner H, Ferrara N, Petzelbauer P and Sibilia M: Autocrine VEGF signaling synergizes with EGFR in tumor cells to promote epithelial cancer development. Cell 140: 268-279, 2010.

33. Li CF, Fang FM, Wang JM, Tzeng CC, Tai HC, Wei YC, Li SH, Lee YT, Wang YH, Yu SC, et al: EGFR nuclear import in gallbladder carcinoma: Nuclear phosphorylated EGFR upregulates iNOS expression and confers independent prognostic impact. Ann Surg Oncol 19: 443-454, 2012.

34. Chen S, Hou JH, Feng XY, Zhang XS, Zhou ZW, Yun JP, Chen YB and Cai MY: Clinicopathologic significance of putative stem cell marker, CD44 and CD133, in human gastric carcinoma. J Surg Oncol 107: 799-806, 2013.

35. Britton KM, Eyre R, Harvey IJ, Stemke-Hale K, Browell D, Lennard TW and Meeson AP: Breast cancer, side population cells and ABCG2 expression. Cancer Lett 323: 97-105, 2012.

36. Ping YF, Yao XH, Jiang JY, Zhao LT, Yu SC, Jiang T, Lin MC, Chen JH, Wang B, Zhang R, et al: The chemokine CXCL12 and its receptor CXCR4 promote glioma stem cell-mediated VEGF production and tumour angiogenesis via PI3K/AKT signaling. J Pathol 224: 344-354, 2011. 